\title{
GAMBARAN PELAKSANAAN KEGIATAN KEBERSIHAN TANGAN OLEH PETUGAS KESEHATAN DI RUMAH SAKIT DUSTIRA CIMAHI
}

\author{
Shely Silfia Ratna Ningsih ${ }^{1}$, Richa Noprianty ${ }^{2}$, Irman Somantri ${ }^{3}$ \\ ${ }^{1,2}$ Program Studi S1 Keperawatan, Sekolah Tinggi Ilmu Kesehatan Dharma Husada \\ ${ }^{3}$ Fakultas Ilmu Keperawatan, Universitas Padjajaran \\ Email : ${ }^{2}$ richa.noprianty@gmail.com
}

\begin{abstract}
ABSTRAK
Keselamatan pasien merupakan variabel untuk mengukur dan mengevaluasi kualitas pelayanan keperawatan. Salah satu upaya yang dilakukan adalah mencegah infeksi rumah sakit dengan menjaga kebersihan tangan dengan teknik enam langkah dan lima momen di rawat inap. Penelitian ini bertujuan untuk mengetahui gambaran pelaksanaan kebersihan tangan oleh petugas kesehatan di Ruang Rawat Inap Penyakit Dalam Pria Rumah Sakit Dustira Cimahi. Jenis penelitian ini adalah deskriptif eksploratif dengan metode observasional. Sampel penelitian ini berjumlah 288 kali pengamatan kegiatan oleh petugas kesehatan (dokter, perawat dan mahasiswa praktek) yang terbagi pada shift pagi dan shift sore dengan 84 pengamatan, dan shift malam berjumlah 120 kali pengamatan. Instrumen penelitian menggunakan lembar observasi dengan menggunakan work sampling. Hasil menggambarkan bahwa : 1) sebelum kontak dengan pasien sebagian besar hand hygiene tidak dilakukan oleh mahasiswa yaitu sebesar 89,8 \% pada shift malam, 2) sebelum tindakan terhadap pasien sebagian besar hand hygiene tidak dilakukan oleh mahasiswa sebanyak $89,8 \%$ pada shift malam, 3) sesudah kontak dengan pasien sebagian besar kegiatan hand hygiene dilakukan tidak sempurna oleh dokter sebanyak $75 \%$ pada shift sore, 4) sesudah kontak dengan cairan tubuh pasien sebagian besar hand hygiene dilakukan tidak sempurna oleh mahasiswa sebanyak $82,4 \%$ pada shift pagi, dan 5) sesudah kontak dengan lingkungan pasien sebagian besar hand hygiene dilakukan tidak sempurna oleh dokter sebanyak $75 \%$ pada shift sore. Berdasarkan hasil observasi, ketidak patuhan pelaksanaan kegiatan kebersihan tangan disebabkan karena media yang digunakan kurang memadai seperti campuran air pada sabun yang terlalu banyak, tisu yang jarang tersedia, antiseptik berbasis alkohol murni sehingga menimbulkan bau yang menyengat dan terasa panas ditangan serta lengket. Disarankan bagi pihak rumah sakit untuk memperhatikan kembali sarana dan prasarana untuk menunjang kebersihan tangan dan bagi petugas kesehatan disarankan untuk membaca kembali standar operasional prosedur (SOP) dari setiap tindakan yang akan dilakukan, karena setiap tindakan yang dilakukan ada SOP untuk mencuci tangan.
\end{abstract}

Kata Kunci: Kebersihan tangan, Lima momen, Petugas kesehatan

\section{ABSTRACT}

Patient safety is a variable for measuring and evaluating the quality of nursing services. One of the effort that should be done is to prevent hospital infections with hand hygiene using six-step hand hygiene technique and five moments at the hospitalization rooms. This study aims to describe the implementation of hand hygiene practice by healthcare provider in patient safety activities atmale medical ward on Dustira Cimahi Hospital. The study was a descriptive exploratory with the observational method. The research sample numbering 288 times observation activities from health workers (doctors, nurses, and students college) that divided on the morning shift totaling 84 observation activities, totaling 84 observations afternoon shift and night shift activities amounted to 120 times the observation activities. The instrument of this study using observation tool which contains a table check list on the implementation of hand hygiene by using work sampling. The overall results describe that: 1) not doing hand hygiene activities before making contact with the patient, were $89,8 \%$ for college students at the night shift, 2) before taking action at the patient most of the hand hygiene activities were not done $89,8 \%$ 
for college students in night shift, 3) after making contact with the patient, most of the hand hygiene activities were not perfect carried out, $75 \%$ for doctors in the afternoon shift, 4) after making contact with patients body fluids most of the hand hygiene activities were not done $82,4 \%$ for the college students in the morning shift, and 5) after making contact with the patient's environment most of the hand hygiene activities were not perfect carried out, 75\% for doctors in the afternoon shift. Based on the observation, disobedience on implementation of hand hygiene due to insufficient media used liketoo much water in the mixture of water and soap, tissue is rarely available, pure alcohol-based hand rub is causing bad smell, hot at the skin and sticky hands. It is advised for the hospital to pay attention at infrastructure that support hand hygiene, and for health workers is advised to re-read the standard operating procedures (SOP) on any action to be performed, for every action there is SOP towash the hand.

Keywords: Hand Hygiene, Five Moments, Health Workers

\section{PENDAHULUAN}

Keselamatan pasien merupakan variabel untuk mengukur dan mengevaluasi kualitas pelayanan keperawatan yang berdampak terhadap pelayanan kesehatan. Publikasi terbaru di Amerika tahun 2011 menunjukkan bahwa satu dari tiga pasien yang dirawat di rumah sakit mengalami kejadian tidak diinginkan (KTD). Jenis yang tersering adalah kesalahan pengobatan, kesalahan operasi dan prosedur serta infeksi nosokomial (Utarini, 2011). Studi di sepuluh rumah sakit di North Carolina menemukan hasil yang serupa. Menurut Landrigan (2010), satu dari empat pasien rawat inap mengalami KTD, 63\% diantaranya sebenarnya dapat dicegah. Pencegahan infeksi di rumah sakit dapat dilkukan oleh petugas kesehatan, keluarga pasien dan pasien sendiri dengan memperhatikan hand hygiene sebagai upaya untuk patient safety.

Salah satu pencegahan infeksi rumah sakit adalah dengan menjaga kebersihan tangan (Khoiriyati, 2013). Kepatuhan petugas kesehatan dalam melakukan hand hygiene dengan teknik enam langkah dan waktu lima momen (five moments) di rawat inap merupakan salah satu indikator mutu area sasaran patient safety yang ada pada Standar Pelayanan Minimal (SPM).
Petugas kesehatan harus menerapkan five moments for hand hygiene, yaitu: sebelum menyentuh pasien, sebelum melakukan prosedur kebersihan atau aseptik, setelah berisiko terpajan cairan tubuh, setelah bersentuhan dengan pasien, dan setelah bersentuhan dengan lingkungan pasien, termasuk permukaan atau barang-barang yang tercemar. Sedangkan untuk enam langkah cuci tangan adalah : 1) menggosok bagian dalam telapak tangan, 2) menggosok punggung tangan bergantian, 3) menggosok sela-sela jari tangan, 4) menggosok ruas jari tangan dengan mengkaitkan kedua tangan, 5) menggosok ibu jari tangan bergantian, dan 6) menggosok ujung jari tangan (Depkes RI, 2013).

Chou et al (2010) mengatakan bahwa penerapan hand hygiene oleh perawat belum sepenuhnya dijalankan dengan baik oleh petugas. Sama halnya dengan yang ada di American Journal of Infection Controle mengemukakan bahwa kebersihan tangan adalah metode terbaik untuk mencegah penularan infeksi dalam perawatan kesehatan, tetapi kepatuhan biasanya suboptimal, selain itu mengubah budaya mencuci tangan menggunakan surat pelanggaran menjadi faktor utama dalam meningkatkan tingkat kepatuhan hand hygiene dari 34\% sampai > 90\% dalam jangka waktu dua tahun. 
Pendidikan sebagai sosialisasi program dapat meningkatkan kepatuhan hand hygiene dengan five moments (Jamaluddin, 2012). Hasil penelitian oleh Damanik (2012), diperoleh kepatuhan perawat melakukan hand hygiene sebesar 48,3\% dan ada hubungan yang bermakna antara masa kerja $(p=0,026)$, pengetahuan $(\mathrm{p}=0,000)$, dan ketersediaan tenaga kerja $(\mathrm{p}=0,000)$ dengan kepatuhan melakukan hand hygiene. Ketersediaan tenaga kerja merupakan faktor paling dominan dalam melakukan hand hygiene. Sedangkan hasil penelitian dari Widyanita dan Listiowati (2014) menunjukkan dari 31 responden diperoleh responden dengan kepatuhan cuci tangan kurang berjumlah 26 orang $(83,9 \%)$ dan responden yang patuh cuci tangan berjumlah lima orang $(16,1 \%)$.

Tenaga kesehatan yang paling sering melakukan tindakan terhadap pasien di ruang penyakit dalam adalah dokter, perawat dan mahasiswa praktik. Hampir setiap bulan ada mahasiswa praktik sehingga peneliti menjadikan petugas kesehatan baik dokter, perawat maupun mahasiswa praktik dijadikan subjek untuk penelitian ini karena pelaksanaan hand hygiene dengan handwash dan handrub dalam five moments oleh petugas kesehatan harus dilaksanakan (Ernawati, 2011).

Hand hyegiene dengan menggunakan handwash maupun handrub tekniknya sama saja yaitu dengan enam langkah, waktu pelaksanaannya juga sama yaitu dengan five moments, yang membedakan hanyalah pada medianya, yaitu dimana pada handwash menggunakan sabun dan air mengalir, sedangkan handrub dengan media antiseptik berbasis alkohol (Salim, 2013;
Krishnan, et al, 2015). Berdasarkan hasil wawancara didapatkan perawat dan mahasiswa tersebut menyatakan membutuhkan waktu lama jika kita harus melaksanakan kegiatan hand hygiene menggunakan five moments baik dengan handwash maupun handrub.

\section{METODE}

Jenis penelitian adalah deskriptif eksploratif. Populasi pada penelitian ini adalah jumlah seluruh aktivitas atau kegiatan petugas kesehatan (dokter, perawat dan mahasiswa keperawatan baik D3, S1 atau ners yang sedang praktik) di ruang rawat inap penyakit dalam pria (Ruang XI) rumah sakit Dustira.Penelitian ini menggunakan teknik probability sampling dengan pengambilan sampel random sampling dengan mengacak kegiatan hand hygiene untuk mendapatkan personel sebagai representasi populasi subjek yang akan diamati dalam 24 jam selama tiga shift dalam tiga hari yaitu hari pertama untuk shift pagi, hari ke dua untuk shif sore, dan hari ke tiga untuk shift malam dengan waktu pengamatan selama 5 menit karena rata-rata lamanya kegiatan yang dilakukan di ruang rawat Dustira adalah 5 menit. Penghitungan jumlah pengamatan sampel yang digunakan dengan metode Ilyas (2008) dapat dihitung sebagai berikut:

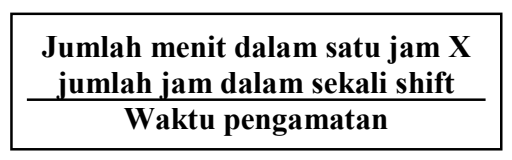

sehingga didapatkan sampel pengamatan per shift sebagai berikut :

Tabel 1. Jumlah sampel pengamatan

\begin{tabular}{|c|c|c|}
\hline Shift & $\begin{array}{c}\text { Waktu } \\
\text { shift }\end{array}$ & Hasil \\
\hline Pagi & 7 jam & $\begin{array}{l}(60 \text { menit } \times 7 \text { jam }) / 5 \\
\text { menit }=84 \text { pengamatan }\end{array}$ \\
\hline Sore & 7 jam & $\begin{array}{l}(60 \text { menit } \times 7 \text { jam }) / 5 \\
\text { menit }=84 \text { pengamatan }\end{array}$ \\
\hline Malam & $10 \mathrm{jam}$ & $\begin{array}{l}(60 \text { menit } \times 10 \text { jam }) / 5 \\
\text { menit }=120 \text { pengamatan }\end{array}$ \\
\hline $\mathrm{T}$ & apel & 288 pengamatan \\
\hline
\end{tabular}


Instrumen penelitian yang digunakan adalah ini dengan menggunakan alat observasi yang berisi tabel check list dengan instrumen work sampling dari metoe Ilyas (2008) untuk kegiatan enam langkah hand higiene dengan handwash dan handrub serta five moments. dengan interval pengamatan lima menit selama 24 jam dalam waktu tiga shift. Cara pengumpulan data dengan memberikan penilaian pada five moments dengan menceklis nilai tiga jika dilakukan sempurna, dua jika tidak sempurna dan satu jika tidak dilakukan.

Peneliti mengobservasi tiap lima menit sekali kegiatan hand hygiene dalam five moments oleh petugas kesehatan yakni dokter (satu) yang sedang ada kegiatan, tiga perawat disetiap shift karena jadwal shift lebih sering tiga perawat yang jaga, dan dua mahasiswa praktik yang sering dijadwalkan praktik untuk dijadikan sampel tanpa melihat subjeknya dengan tiga kali pengambilan data yaitu pada shift pagi, shift sore dan shift malam.

Pada saat mengambil data, peneliti menggunakan asisten peneliti yaitu perawat pelaksana dengan jenjang pendidikan diploma keperawatan yang bertugas di ruangan lain untuk menghindari data bias. Kemudian peneliti dan asisten peneliti mengamati aktfitas yang dilakukan oleh petugas kesehatan pada saat itu dengan skala penilaian yang melakukan hand hygiene dengan enam langkah sempurna, yang melakukan hand hygiene dengan tidak sempurna dan yang tidak melakukan hand hygiene dengan metode work sampling. Kemudian pengamatan kegiatan sampel dilakukan dengan interval lima menit selama 24 jam dalam tiga shift (pagi, siang dan malam) selama tiga hari yaitu hari pertama untuk shift pagi, hari kedua untuk shift sore dan hari ke tiga untuk shif malam.

\section{HASIL}

Pelaksanaan Pengamatan Kegiatan Hand Hygiene oleh Petugas Kesehatan pada Shift Pagi
Berdasarkan Tabel 2 dapat dilihat nilai prosentase yang paling tinggi petugas kesehatan yang tidak melakukan kegiatan hand hygiene pada shift pagi pada saat sebelum melakukan kontak dengan pasien oleh mahasiswa sebanyak $25(73,5 \%)$, sebelum melakukan tindakan terhadap pasien oleh mahasiswa sebanyak 23 (67,6\%), sesudah melakukan kontak dengan pasien oleh perawat sebanyak $16(38,1 \%)$, sesudah melakukan kontak dengan cairan tubuh oleh perawat sebanyak $16(38,1 \%)$ dan sesudah melakukan kontak dengan lingkungan pasien oleh perawat sebanyak $16(38,1 \%)$.

\section{Pelaksanaan Pengamatan Kegiatan Hand Hygiene oleh Petugas Kesehatan pada Shift Sore}

Berdasarkan Tabel 3 dapat dilihat nilai prosentase yang paling tinggi petugas kesehatan yang tidak melakukan kegiatan hand hygiene pada shift sore pada saat sebelum melakukan kontak dengan pasien oleh mahasiswa sebanyak $29(80,6 \%)$, sebelum melakukan tindakan terhadap pasien oleh mahasiswa sebanyak 29 (80,6\%), sesudah melakukan kontak dengan pasien oleh dokter sebanyak $1(25,0 \%)$, sesudah melakukan kontak dengan cairan tubuh oleh perawat sebanyak $14(31,8 \%)$ dan sesudah melakukan kontak dengan lingkungan pasien oleh dokter sebanyak $1(25 \%)$.

\section{PEMBAHASAN}

Pelaksanaan Pengamatan Kegiatan Hand Hygiene oleh Petugas Kesehatan Secara Keseluruhan

Kegiatan menunjukkan pada pelaksanaan kegiatan hand hygiene didapatkan nilai prosentase yang paling tinggi petugas kesehatan yang tidak melakukan kegiatan hand hygiene dalam kegiatan five moments terdapat pada kegiatan: 1) sebelum melakukan kontak dengan pasien, sebagian besar tidak melakukan hand higiene dilakukan oleh mahasiswa sebanyak $82,9 \%$, 2) sebelum melakukan tindakan ke pasien, sebagian besar tidak melakukan hand higiene dilakukan oleh mahasiswa sebanyak $81,4 \%$. Untuk kegiatan 3) sesudah melakukan kontak dengan pasien 
Tabel 2. Pelaksanaan kegiatan hand hygiene oleh petugas kesehatan pada shift pagi

\begin{tabular}{|c|c|c|c|c|}
\hline \multirow{2}{*}{$\begin{array}{c}\text { Tenaga } \\
\text { Kesehatan }\end{array}$} & \multicolumn{4}{|c|}{ Kegiatan Hand Hygiene } \\
\hline & $\begin{array}{c}\text { Tidak } \\
\text { Dilakukan }\end{array}$ & Tidak Sempurna & Dilakukan Sempurna & Total \\
\hline \multicolumn{5}{|c|}{ Sebelum Kontak dengan Pasien } \\
\hline Dokter & $4(50,0 \%)$ & $3(37,5 \%)$ & $1(12,5 \%)$ & $8(100 \%)$ \\
\hline Perawat & $24(57,1 \%)$ & $15(35,7 \%)$ & $3(7,1 \%)$ & $42(100 \%)$ \\
\hline Mahasiswa & $25(73,5 \%)$ & $9(26,5 \%)$ & $0(0,0 \%)$ & $34(100 \%)$ \\
\hline Total & $53(63,1 \%)$ & $27(32,1 \%)$ & $4(4,8 \%)$ & $84(100 \%)$ \\
\hline \multicolumn{5}{|c|}{ Sebelum Tindakan dengan Pasien } \\
\hline Dokter & $4(50,0 \%)$ & $3(37,5 \%)$ & $1(12,5 \%)$ & $8(100 \%)$ \\
\hline Perawat & $26(61,9 \%)$ & $13(31,0 \%)$ & $3(7,1 \%)$ & $42(100 \%)$ \\
\hline Mahasiswa & $23(67,6 \%)$ & $11(32,4 \%)$ & $0(0,0 \%)$ & $34(100 \%)$ \\
\hline Total & $53(63,1 \%)$ & $27(32,1 \%)$ & $4(4,8 \%)$ & $84(100 \%)$ \\
\hline \multicolumn{5}{|c|}{ Sesudah Kontak dengan Pasien } \\
\hline Dokter & $3(37,5 \%)$ & $4(50,0 \%)$ & $1(12,5 \%)$ & $8(100 \%)$ \\
\hline Perawat & $16(38,1 \%)$ & $23(54,8 \%)$ & $3(7,1 \%)$ & $42(100 \%)$ \\
\hline Mahasiswa & $8(23,5 \%)$ & $25(73,5 \%)$ & $1(2,9 \%)$ & $34(100 \%)$ \\
\hline Total & $27(32,1 \%)$ & $52(61,9 \%)$ & $5(6,0 \%)$ & $84(100 \%)$ \\
\hline \multicolumn{5}{|c|}{ Sesudah Kontak dengan Cairan Tubuh Pasien } \\
\hline Dokter & $3(37,5 \%)$ & $4(50,0 \%)$ & $1(12,5 \%)$ & $8(100 \%)$ \\
\hline Perawat & $16(38,1 \%)$ & $23(54,8 \%)$ & $3(7,1 \%)$ & $42(100 \%)$ \\
\hline Mahasiswa & $5(14,7 \%)$ & $28(82,4 \%)$ & $1(2,9 \%)$ & $34(100 \%)$ \\
\hline Total & $24(28,6 \%)$ & $55(65,5 \%)$ & $5(6,0 \%)$ & $84(100 \%)$ \\
\hline \multicolumn{5}{|c|}{ Sesudah Kontak dengan Lingkungan Pasien } \\
\hline Dokter & $3(37,5 \%)$ & $4(50,0 \%)$ & $1(12,5 \%)$ & $8(100 \%)$ \\
\hline Perawat & $16(38,1 \%)$ & $23(54,8 \%)$ & $3(7,1 \%)$ & $42(100 \%)$ \\
\hline Mahasiswa & $12(35,3 \%)$ & $21(61,8 \%)$ & $1(2,9 \%)$ & $34(100 \%)$ \\
\hline Total & $31(36,9 \%)$ & $48(57,1 \%)$ & $5(6,0 \%)$ & $84(100 \%)$ \\
\hline
\end{tabular}

sebagian besar tidak melakukan hand higiene dilakukan oleh dokter sebanyak 38,9\%, 4) sesudah melakukan kontak dengan cairan tubuh pasien sebagian besar tidak melakukan hand higiene dilakukan oleh perawat sebanyak $39 \%$, dan 5) sesudah melakukan kontak dengan lingkungan pasien sebagian besar tidak melakukan hand higiene dilakukan oleh dokter sebanyak 38,9\%.

Penelitian ini sejalan dengan hasil penelitian Widyanita dan Listiowati (2014) menunjukkan dari 31 responden diperoleh responden dengan kepatuhan cuci tangan kurang berjumlah 26 orang $(83,9 \%)$ dan responden yang patuh cuci tangan berjumlah lima orang $(16,1 \%)$. Pada praktik di lapangan memang masih banyak yang belum menerapkan hand higiene dengan five moment dengan maksimal.

Berdasarkan hasil observasi peneliti, ketidak patuhan pelaksanaan kegiatan hand hygiene dalam kegiatan five moments 
disebabkan karena media yang digunakan kurang memadai seperti campuran air pada sabun yang terlalu banyak, tisu yang jarang tersedia, antiseptik berbasis alkohol murni sehingga menimbulkan bau yang menyengat dan terasa panas ditangan serta lengket. Perlu adanya simulasi kembali dan berulang sebelum operan untuk mengingatkan kembali dalam upaya pelaksanaan hand higiene dengan teknik enam langkah dan five moment. Hal ini sudah dibuktikan dari hasil penelitian didapatkan, pelaksanaan hand hygiene sebelum intervensi (simulasi hand hygiene pada handover keperawatan) sebesar 39,17\%, dimana persentase perawat yang melakukan hand hygiene sesuai dengan prosedur yang benar $0 \%$. Pelaksanaan hand hygiene meningkat setelah intervensi menjadi $61,66 \%$ dengan persentase pelaksanaan hand hygiene yang benar sebesar $40,83 \%$.

Kurangnya pelaksanaan kegiatan hand hygiene yang dilakukan oleh petugas kesehatan akan memberikan dampak yang sangat besar pagi pasien maupun petugas kesehatan itu sendiri. Dampak tersebut salah satunya seperti infeksi nosokomial dan flebitis yang sebenarnya dapat dicegah yaitu dengan hand hygiene dalam kegiatan five moments (Napitupulu, 2015).

\section{Pelaksanaan Pengamatan Kegiatan Hand Hygiene Berdasarkan Shift Pagi}

Berdasarkan hasil penelitian yang telah dilakukan kepada petugas kesehatan nilai prosentase yang paling tinggi petugas kesehatan yang tidak melakukan kegiatan hand hygiene pada shift pagi pada saat sebelum melakukan kontak dengan pasien oleh mahasiswa sebanyak 25 (73,5\%), sebelum melakukan tindakan terhadap pasien oleh mahasiswa sebanyak $23(67,6 \%)$, sesudah melakukan kontak dengan pasien oleh perawat sebanyak $16(38,1 \%)$, sesudah melakukan kontak dengan cairan tubuh oleh perawat sebanyak $16(38,1 \%)$ dan sesudah melakukan kontak dengan lingkungan pasien oleh perawat sebanyak $16(38,1 \%)$. Hal ini dikarenakan pada shift pagi banyak melakukan tindakan keperawatan dan invasif ke pasien oleh perawat ruangan sehingga banyak tindakan seperti mengecek tanda-tanda vital, pemenuhan kebutuhan dasar manusia ataupun mengantarkan pasien untuk pemeriksaan banyak melibatkan mahasiswa. Sehingga dengan banyaknya kegiatan menjadi alasan utama petugas kesehatan kurang memperhatikan hand higiene dan penerapan five moment.

Berdasarkan hasil observasi peneliti ketidak sempurnaan pelaksanaan kegiatan hand hygiene dalam kegiatan five moments disebabkan karena kegiatan pada shift pagi lebih banyak dibandingkan dengan shift lainnya sehingga lebih banyak pula kegiatan yang memungkinkan untuk mencuci tangan pada five moments walaupun tidak sempurna. Sehingga sangat berisiko untuk penularan infeksi nosokomial dan flebitis baik dari petugas kesehatan kepada pasien maupun dari pasien kepada petugas kesehatan.

Pengamatan peneliti yang dilakukan pada shift pagi sebagian besar kegiatan yang terjadi pada ruang rawat inap rumah sakit dustira yaitu dimulai dari operan, melakukan bed making, visit dokter, memeriksa pasien, mengganti cairan infus, memasang infus, mengambil specimen darah, mengambil specimen urine, mengambil specimen dahak, memberikan terapi oksigen, melakukan Elektrokardiografi (EKG), menyiapkan obat oral, mengantar pasien untuk pemeriksaan Ultrasonografi (USG), mengantar pasien untuk pemeriksaan foto thorax, mengantar pasien untuk hemodialisa, memberikan terapi injeksi, melakukan pemeriksaan tanda-tanda vital, memberikan terapi melalui selang Nasogastric Tube (NGT), memberikan terapi oral, pendokumentasian dan lain sebagainya merupakan kegiatan yang rutin dilakukan oleh petugas kesehatan (dokter, perawat dan mahasiswa keperawatan baik D3, S1 atau ners yang sedang praktik) pada shift pagi yang selalu berhubungan langsung dengan pasien, sehingga pelaksanaan kegiatan hand hygiene dalam five moment sangatlah penting dan harus diterapkan untuk meningkatkan patient safety.

Ketidak sempurnaan pelaksanaan hand hygiene dalam five moment oleh petugas kesehatan (dokter, perawat dan mahasiswa keperawatan baik D3, S1 atau ners yang sedang praktik) pada shift pagi dari hasil pengamatan peneliti disebabkan karena media yang digunakan kurang memadai seperti sabun yang dicampur dengan air yang terlalu banyak, tisu yang jarang tersedia, antiseptik berbasis alkohol murni sehingga menimbulkan bau yang menyengat dan terasa panas ditangan 


\begin{tabular}{|c|c|c|c|c|}
\hline \multirow{2}{*}{$\begin{array}{c}\text { Tenaga } \\
\text { Kesehatan }\end{array}$} & \multicolumn{4}{|c|}{ Kegiatan Hand Hygiene } \\
\hline & Tidak Dilakukan & Tidak Sempurna & Dilakukan Sempurna & Total \\
\hline \multicolumn{5}{|c|}{ Sebelum Kontak dengan Pasien } \\
\hline Dokter & $3(75,0 \%)$ & $1(25,0 \%)$ & $0(0,0 \%)$ & $4(100 \%)$ \\
\hline Perawat & $18(40,9 \%)$ & $24(54,5 \%)$ & $2(4,5 \%)$ & $44(100 \%)$ \\
\hline Mahasiswa & $29(80,6 \%)$ & $4(11,1 \%)$ & $3(8,3 \%)$ & $36(100 \%)$ \\
\hline Total & $50(59,5 \%)$ & $29(34,5 \%)$ & $5(6,0 \%)$ & $84(100 \%)$ \\
\hline \multicolumn{5}{|c|}{ Sebelum Tindakan dengan Pasien } \\
\hline Dokter & $3(75,0 \%)$ & $1(25,0 \%)$ & $0(0,0 \%)$ & $4(100 \%)$ \\
\hline Perawat & $18(40,9 \%)$ & $24(54,5 \%)$ & $2(4,5 \%)$ & $44(100 \%)$ \\
\hline Mahasiswa & $29(80,6 \%)$ & $4(11,1 \%)$ & $3(8,3 \%)$ & $36(100 \%)$ \\
\hline Total & $50(59,5 \%)$ & $29(34,5 \%)$ & $5(6,0 \%)$ & $84(100 \%)$ \\
\hline \multicolumn{5}{|c|}{ Sesudah Kontak dengan Pasien } \\
\hline Dokter & $1(25,0 \%)$ & $3(75,0 \%)$ & $0(0,0 \%)$ & $4(100 \%)$ \\
\hline Perawat & $8(18,2 \%)$ & $29(65,9 \%)$ & $7(15,9 \%)$ & $44(100 \%)$ \\
\hline Mahasiswa & $6(16,7 \%)$ & $26(72,2 \%)$ & $4(11,1 \%)$ & $36(100 \%)$ \\
\hline Total & $15(17,9 \%)$ & $58(69,0 \%)$ & $11(13,1 \%)$ & $84(100 \%)$ \\
\hline \multicolumn{5}{|c|}{ Sesudah Kontak dengan Cairan Tubuh Pasien } \\
\hline Dokter & $1(25,0 \%)$ & $3(75,0 \%)$ & $0(0,0 \%)$ & $4(100 \%)$ \\
\hline Perawat & $14(31,8 \%)$ & $25(56,8 \%)$ & $5(11,4 \%)$ & $44(100 \%)$ \\
\hline Mahasiswa & $4(11,1 \%)$ & $26(72,2 \%)$ & $6(16,7 \%)$ & $36(100 \%)$ \\
\hline Total & $19(22,6 \%)$ & $54(64,3 \%)$ & $11(13,1 \%)$ & $84(100 \%)$ \\
\hline \multicolumn{5}{|c|}{ Sesudah Kontak dengan Lingkungan Pasien } \\
\hline Dokter & $1(25,0 \%)$ & $3(75,0 \%)$ & $0(0,0 \%)$ & $4(100 \%)$ \\
\hline Perawat & $10(22,7 \%)$ & $27(61,4 \%)$ & $7(15,9 \%)$ & $44(100 \%)$ \\
\hline Mahasiswa & $6(16,7 \%)$ & $26(72,2 \%)$ & $4(11,1 \%)$ & $36(100 \%)$ \\
\hline Total & $17(20,2 \%)$ & $56(66,7 \%)$ & $11(13,1 \%)$ & $84(100 \%)$ \\
\hline
\end{tabular}

serta lengket. Selain itu, pada shift pagi kegiatan yang dilakukan cukup banyak. Sehingga dengan banyaknya kegiatan tersebut membuat petugas kesehatan malas untuk melakukan hand hygiene dengan enam langkah sempurna.

Hal tersebut senada dengan hasil penelitian Ernawati, et al (2011) tentang kepatuhan hand hygiene perawat ruang rawat inap rumah sakit X di Malang masih rendah (35\%). Angka kepatuhan yang tinggi ditemukan pada momen sesudah kontak atau melakukan tindakan sedangkan kepatuhan cuci tangan sebelum kontak sangat rendah bahkan tidak ada perawat yang melaksanakan hand hygiene pada momen sebelum kontak dengan pasien.

\section{Pelaksanaan Pengamatan Kegiatan Hand Hygiene Berdasarkan Shift Sore}

Berdasarkan hasil penelitian yang telah dilakukan kepada petugas kesehatan nilai prosentase yang paling tinggi petugas kesehatan yang tidak melakukan kegiatan hand hygiene pada shift sore pada saat sebelum melakukan kontak dengan pasien oleh 
mahasiswa sebanyak $29(80,6 \%)$, sebelum melakukan tindakan terhadap pasien oleh mahasiswa sebanyak 29 (80,6\%), sesudah melakukan kontak dengan pasien oleh dokter sebanyak $1(25,0 \%)$, sesudah melakukan kontak dengan cairan tubuh oleh perawat sebanyak $14(31,8 \%)$ dan sesudah melakukan kontak dengan lingkungan pasien oleh dokter sebanyak $1(25 \%)$.

Berdasarkan observasi peneliti ketidak sempurnaan pelaksanaan kegiatan hand hygiene dalam kegiatan five moments disebabkan karena kegiatan pada shift sore banyak tindakan yang harus dilakukan tetapi tenaga kesehatan lebih sedikit, sehingga petugas kesehatan tidak terlalu memperhatikan teknik enam langkah cuci tangan sempurna karena tidak terpajan oleh cairan tubuh pasien. Sehingga berisiko untuk penularan infeksi nosokomial dan flebitis baik dari petugas kesehatan kepada pasien maupun dari pasien kepada petugas kesehatan.

Pengamatan peneliti yang dilakukan pada shift sore sebagian besar kegiatan yang terjadi pada ruang rawat inap rumah sakit dustira yaitu dimulai dari operan, melakukan bed making, visit dokter, memeriksa pasien, mengganti cairan infus, memasang infus, mengambil specimen darah, memberikan terapi oksigen, menyiapkan terapi injeksi, memberikan terapi nebulizer, membilas lambung, melakukan Elektrokardiografi (EKG), menyiapkan obat oral, mengantar pasien untuk pemeriksaan Ultrasonografi (USG), mengantar pasien untuk pemeriksaan foto thorax, mengantar pasien untuk hemodialisa, memberikan terapi injeksi, melakukan pemeriksaan tanda-tanda vital, memberikan terapi melalui selang Nasogastric Tube (NGT), memberikan terapi oral, pendokumentasian dan lain sebagainya merupakan kegiatan yang rutin dilakukan oleh petugas kesehatan (dokter, perawat dan mahasiswa keperawatan baik D3, S1 atau ners yang sedang praktik) pada shift sore yang selalu berhubungan langsung dengan pasien, sehingga pelaksanaan kegiatan hand hygiene dalam five moment sangatlah penting dan harus diterapkan untuk meningkatkan patient safety.

Pengamatan peneliti didapatkan bahwa ketidak sempurnaan pelaksanaan hand hygiene dalam five moment oleh petugas kesehatan (dokter, perawat dan mahasiswa keperawatan baik D3, S1 atau ners yang sedang praktik) pada shift sore dikarenakan media yang digunakan kurang memadai seperti campuran air pada sabun yang terlalu banyak, tisu yang jarang tersedia, antiseptik berbasis alkohol murni sehingga menimbulkan bau yang menyengat dan terasa panas ditangan serta lengket. Selain itu, pada shift sore kegiatan yang dilakukan cukup banyak dan sedikitnya petugas kesehatan yang dijadwalkan berdinas. Sehingga dengan banyaknya kegiatan tersebut membuat petugas kesehatan kurang memperhatikan untuk melakukan hand hygiene dengan enam langkah sempurna.

Hal ini sama dengan hasil penelitian Damanik (2012), didapatkan kepatuhan perawat melakukan hand hygiene sebesar $48,3 \%$ dan ada hubungan yang bermakna antara masa kerja $(p=0,026)$, pengetahuan ( $p$ $=0,000)$, dan ketersediaan tenaga kerja $(\mathrm{p}=$ $0,000)$ dengan kepatuhan melakukan hand hygiene. Ketersediaan tenaga kerja merupakan faktor paling dominan dalam melakukanhand hygiene.

Penelitian ini juga didukung dengan hasil penelitian Sofyani (2012) tentang persepsi perawat mengenai factor-faktor yang mempengaruhi pemenuhan hand hygiene di ICU Rumah Sakit MH. Thamrin Salemba adalah faktor kurangnya pengetahuan perawat mengenai teknik dan lima waktu pelaksanaan hand hygiene, beban kerja yang lebih tinggi dan kekurangan tenaga, masih kurangnya jumlah wastafel dan letaknya yang jauh. Alasan lainnya yaitu saat menangani kondisi darurat, perawat merasa prosedur hand hygiene merepotkan, faktor malas, air yang mati atau keran yang rusak.

\section{Pelaksanaan Pengamatan Kegiatan Hand Hygiene Berdasarkan Shift Malam}

Berdasarkan hasil penelitian yang telah dilakukan kepada petugas kesehatan nilai prosentase yang paling tinggi petugas kesehatan yang tidak melakukan kegiatan hand hygiene pada shift malam pada saat sebelum melakukan kontak dengan pasien oleh mahasiswa sebanyak 53 (89,8\%), sebelum melakukan tindakan terhadap pasien oleh mahasiswa sebanyak 53 (89,8\%), sesudah melakukan kontak dengan pasien oleh dokter sebanyak $3(50,0 \%)$, sesudah melakukan kontak dengan cairan tubuh oleh dokter sebanyak 3 (50,0\%) dan sesudah melakukan kontak dengan lingkungan pasien oleh dokter 
sebanyak 3 (50,0\%). Hal ini dikarenakan pada saat shift malam terdapat waktu yang panjang tetapi kegiatan yang dilakukan sama dengan shift pagi dan sore, sehingga petugas kesehatan kurang memperhatikan pelaksanaan kegiatan hand hygiene sebelum moments ke pasien dikarenakan sedang melakukan kegiatan lain. Tetapi pada kegiatan sesudah ke pasien petugas kesehatan mencuci tangan walaupun dengan tidak sempurna, karena kebanyakan kegiatan pada malam hari yaitu membenarkan selang infus yang macet sehingga risiko terkena cairan tubuh pasien lebih banyak.

Hal tersebut diatas sesuai dengan hasil penelitian Sofyani (2012) tentang persepsi perawat mengenai factor-faktor yang mempengaruhi pemenuhan hand hygiene di ICU Rumah Sakit MH.Thamrin Salemba adalah faktor kurangnya pengetahuan perawat mengenai teknik dan lima waktu pelaksanaan hand hygiene, beban kerja yang lebih tinggi dan kekurangan tenaga, masih kurangnya jumlah wastafel dan letaknya yang jauh.

\begin{tabular}{|c|c|c|c|c|}
\hline \multirow{2}{*}{$\begin{array}{c}\text { Tenaga } \\
\text { Kesehatan }\end{array}$} & \multicolumn{4}{|c|}{ Kegiatan Hand Hygiene } \\
\hline & Tidak Dilakukan & Tidak Sempurna & Dilakukan Sempurna & Total \\
\hline \multicolumn{5}{|c|}{ Sebelum Kontak dengan Pasien } \\
\hline Dokter & $5(83,3 \%)$ & $1(16,7 \%)$ & $0(0,0 \%)$ & $6(100 \%)$ \\
\hline Perawat & $37(67,3 \%)$ & $15(27,3 \%)$ & $3(5,5 \%)$ & $55(100 \%)$ \\
\hline Mahasiswa & $53(89,8 \%)$ & $4(6,8 \%)$ & $2(3,4 \%)$ & $59(100 \%)$ \\
\hline Total & $95(79,2 \%)$ & $20(16,7 \%)$ & $5(4,2 \%)$ & $120(100 \%)$ \\
\hline \multicolumn{5}{|c|}{ Sebelum Tindakan dengan Pasien } \\
\hline Dokter & $5(83,3 \%)$ & $1(16,7 \%)$ & $0(0,0 \%)$ & $6(100 \%)$ \\
\hline Perawat & $38(69,1 \%)$ & $14(25,25 \%)$ & $3(5,5 \%)$ & $55(100 \%)$ \\
\hline Mahasiswa & $53(89,8 \%)$ & $4(6,8 \%)$ & $2(3,4 \%)$ & $59(100 \%)$ \\
\hline Total & $96(80,0 \%)$ & $19(15,8 \%)$ & $5(4,2 \%)$ & $120(100 \%)$ \\
\hline \multicolumn{5}{|c|}{ Sesudah Kontak dengan Pasien } \\
\hline Dokter & $3(50,0 \%)$ & $3(50,0 \%)$ & $0(0,0 \%)$ & $6(100 \%)$ \\
\hline Perawat & $25(45,5 \%)$ & $26(47,3 \%)$ & $4(7,3 \%)$ & $55(100 \%)$ \\
\hline Mahasiswa & $15(25,4 \%)$ & $41(69,5 \%)$ & $3(5,1 \%)$ & $59(100 \%)$ \\
\hline Total & $43(35,8 \%)$ & $70(58,3 \%)$ & $7(5,8 \%)$ & $120(100 \%)$ \\
\hline \multicolumn{5}{|c|}{ Sesudah Kontak dengan Cairan Tubuh Pasien } \\
\hline Dokter & $3(50,0 \%)$ & $3(50,0 \%)$ & $0(0,0 \%)$ & $6(100 \%)$ \\
\hline Perawat & $25(45,5 \%)$ & $26(47,3 \%)$ & $4(7,3 \%)$ & $55(100 \%)$ \\
\hline Mahasiswa & $15(25,4 \%)$ & $41(69,5 \%)$ & $3(5,1 \%)$ & $59(100 \%)$ \\
\hline Total & $43(35,8 \%)$ & $70(58,3 \%)$ & $7(5,8 \%)$ & $120(100 \%)$ \\
\hline \multicolumn{5}{|c|}{ Sesudah Kontak dengan Lingkungan Pasien } \\
\hline Dokter & $3(50,0 \%)$ & $3(50,0 \%)$ & $0(0,0 \%)$ & $6(100 \%)$ \\
\hline Perawat & $25(45,5 \%)$ & $26(47,3 \%)$ & $4(7,3 \%)$ & $55(100 \%)$ \\
\hline Mahasiswa & $18(30,5 \%)$ & $38(64,4 \%)$ & $3(5,1 \%)$ & $59(100 \%)$ \\
\hline Total & $46(38,3 \%)$ & $67(55,8 \%)$ & $7(5,8 \%)$ & $120(100 \%)$ \\
\hline
\end{tabular}


Alasan lainnya yaitu saat menangani kondisi darurat, perawat merasa prosedur hand hygiene merepotkan, faktor malas, air yang mati atau keran yang rusak.

Seluruh petugas kesehatan seharusnya sudah dapat menerapkan hand hygiene dalam five moment karena di ruangan sudah disediakan gambar hand hygiene, gambar five moment dan alat untuk handwash dan handrub. Selain itu hand hygiene merupakan salah satu tindakan yang mudah dan efektif untuk penurunan infeksi nosokomial. Infeksi nosokomial memiliki keterkaitan langsung dengan pemenuhan pelaksanaan hand hygiene, pelaksanaan kegiatan hand hygiene yang sesuai dengan teknik dan waktu yang telah ditentukan yaitu dengan five moments akan menurunkan insiden infeksi nosokomial (Sofyani, 2012).Namun sayangnya, pemenuhan pelaksanaan hand hygiene oleh petugas kesehatan masih tergolong rendah. Penelitian yang dilakukan oleh Salim (2012) menjelaskan bahwa hand hygiene yang dilakukan oleh semua pegawai rumah sakit dapat mencegah terjadinya hospital acquired infections (HAIs) sebesar 15-30 \%.

Pelaksanaan hand hygiene dalam five moments sangat penting karena jika tidak dilaksanakan maka berefek pada masalah baru baik untuk pasien, petugas kesehatan mauapun bagi keluarga dan kerabat yang berkunjung ke rumah sakit. Pelaksanaan hand hygiene yang benar teknik dan waktunya dapat mencegahan penyakit baik dari petugas kesehatan kepada pasien, dari pasien kepada petugas kesehatan, ataupun dari pengunjung lain. Hand hygiene haru diterapkan karena tangan sering menjadi agen yag membawa kuman dan menyebakan pathogen berpindah dari satu orang ke orang lain, baik dengan kontak langsung ataupun kontak tidak langsung (Jamaluddin, 2012). Selain itu melaksanakan hand hygiene dalam five moments juga banyak manfaatnya yaitu untuk melindungi pasien dari bakteri patogen yang ada pada tangan petugas dan untuk melindungi petugas kesehatan dan area sekelilingnya bebas dari bakteri patogen yang berasal dari pasien (Sakamoto et al, 2010).

\section{SIMPULAN}

Berdasarkan penelitian tentang "gambaran pelaksanan kegiatan hand hygiene oleh petugas kesehatan dalam kegiatan patient safety di ruang rawat inap penyakit dalam pria Rumah Sakit Dustira Cimahi" dapat disimpulkan bahwa sebagian besar petugas kesehatan tidak melakukan cuci tangan dengan sempurna, dengan hasil sebagai berikut:

1. Petugas kesehatan yang tidak melakukan kegiatan hand hygiene pada shift pagi pada saat sebelum melakukan kontak dengan pasien oleh mahasiswa sebanyak 25 (73,5\%), sebelum melakukan tindakan terhadap pasien oleh mahasiswa sebanyak 23 (67,6\%), sesudah melakukan kontak dengan pasien oleh perawat sebanyak 16 $(38,1 \%)$, sesudah melakukan kontak dengan cairan tubuh oleh perawat sebanyak $16 \quad(38,1 \%)$ dan sesudah melakukan kontak dengan lingkungan pasien oleh perawat sebanyak $16(38,1 \%)$.

2. Petugas kesehatan yang tidak melakukan kegiatan hand hygiene pada shift sore pada saat sebelum melakukan kontak dengan pasien oleh mahasiswa sebanyak 29 (80,6\%), sebelum melakukan tindakan terhadap pasien oleh mahasiswa sebanyak $29(80,6 \%)$, sesudah melakukan kontak dengan pasien oleh dokter sebanyak 1 $(25,0 \%)$, sesudah melakukan kontak dengan cairan tubuh oleh perawat sebanyak $14 \quad(31,8 \%)$ dan sesudah melakukan kontak dengan lingkungan pasien oleh dokter sebanyak 1 (25\%).

3. Petugas kesehatan yang tidak melakukan kegiatan hand hygiene pada shift malam pada saat sebelum melakukan kontak dengan pasien oleh mahasiswa sebanyak 53 (89,8\%), sebelum melakukan tindakan terhadap pasien oleh mahasiswa sebanyak $53(89,8 \%)$, sesudah melakukan kontak dengan pasien oleh dokter sebanyak 3 $(50,0 \%)$, sesudah melakukan kontak dengan cairan tubuh oleh dokter sebanyak $3(50,0 \%)$ dan sesudah melakukan kontak dengan lingkungan pasien oleh dokter sebanyak $3(50,0 \%)$.

\section{DAFTAR PUSTAKA}

Chou, et al. (2010). Changing The Culture Of Hand Hygiene Compliance Using A Bundle That Includesa Violation Letter. American Journal of Infekction Control. Di unduh dari $\mathrm{http} / / / w w w . a j i c j o u r n a l . o r g$. 
Conrad, et al. (2010). Are short training sessions on hand hygiene effective Preventing hospital_acquired MRSA a time-series analysis. American Journal of Infection Control. Di unduh dari http://www.ajicjournal.org.

Damanik. (2012). Kepatuhan Hand Hygiene di Rumah Sakit Immanuel Bandung, Jurnal Universitas Padjadjaran. Diunduh dari http://jurnal.unpad.ac.id.

Darmadi. (2008). Infeksi Nosokomial Problematika dan Pengendalianya. Jakarta: Salemba Medika.

Depkes RI. (2008). Panduan Naional Keselamatan Pasien Rumah Sakit. Jakarta.

Depkes RI. (2011). Keselamatan Pasien Rumah Sakit. Jakarta

Depkes RI. (2013). Lima Momen Saat Praktek Membersihkan Tangan. Jakarta.

Depkes RI. (2014). Hand Hygiene dengan Sabun. Jakarta

Ernawati, et al. (2011). Penerapan Hand Hygiene Perawat di Ruang Rawat Inap Rumah Sakit. Jurnal Kedokteran Brawijaya. Diunduh dari http://jkb.ub.ac.id.

Ilyas. (2008). Perencanaan Sumber Daya Manusia Rumah Sakit "Teori, Metoda dan Formula". Jakarta: Sagung Seto.

Jamaluddin. (2012). Majalah kedokteran Terapi Intensif: Kepatuhan Cuci Tangan 5 Momen di Unit Perawatan Intensif. Diunduh dari http://perpus.yarsi.ac.id.

Kemenkes, RI. (2014). Profil Kesehatan Indonesia. Departemen Kesehatan Republik Indonesia: Jakarta.

Khoiriyati. (2013). Tingkatkan Keselamatan Pasien dengan Membudayakan Hand Hygiene. [Online]. Di unduh dari http://www.umy.ac.id.

Krishnan, et al. (2015). Alcohol Handrubbing and Chlorhexidine Handwashing are Equally Effective in Removing Methicillin-Resistant Staphylococcus Aureus from Health Care Workers'
Hands: A Randomized Controlled Trial. [Online]. Di unduh dari http://www.ajicjournal.org.

Landrigan et, al. (2010). Hubungan Antara Implementasi SMM ISO 9001 dan Kinerja Klinis Pelayanan SC di RSUP Dr. Sardjito. (Skripsi, Universitas Gadjah Mada). Diunduh dari http://stikeskusumahusada.ac.id.

Napitupulu, (2015). Gambaran Kepatuhan Cuci Tangan pada Petugas Kesehatan Sesuai Prinsip 5 Momen 6 Langkah di Ruang Rawat Inap RSUP Haji Adam Malik Medan. (Skripsi, Universitas Sumatra Utara. Di unduh dari http://repository.usu.ac.id.

Nugraheni, dkk. (2012). Infeksi Nosokomial di RSUD Setjonegoro Kabupaten Wonosobo. Jurnal Universitas Diponerogo. Di unduh dari http://ejournal.undip.ac.id.

Nursalam. (2011). Manajemen Keperawatan dengan Aplikasi dalam Praktik Keperawatan Professional. Jakarta: Salemba Medika.

Sakamoto, et al. (2010). Increased Use of Alcohol-Based Hand Sanitizers and Successful Eradication of MethicillinResistant Staphylococcus Aureus From a Neonatal Intensive Care Unit: A Multivariate Time Series Analysis. American Journal of Infekction Control. Di unduh dari http://www.ajicjournal.org.

Salim, N.A. (2013). Pelatihan Hand Hygine Dalam Pencegahan \& Pengendalian Infeksi. (Online]. Diunduh dari http://www.mutupelayanankesehatan. net.

Sofyani, A. (2012). Persepsi Perawat Tentang Pemenuhan Pelaksanaan Hand Hygiene Perawat Di Intensive Care Unit (ICU) Rumah Sakit MH Thamrin Salemba. (Skripsi, Universitas Indonesia). Di unduh dari www.lib.ui.ac.id. 
Utarini, A. (2011). Mutu Pelayanan Kesehatan di Indonesia: Sistem Regulasi yang Responsif. [Online]. Diunduh dari http://www.kebijakankesehatanindon esia.net.

Widyanita dan Listiowati. (2014). Hubungan Tingkat Pengetahuan Hand Hygiene Dengan Kepatuhan Pelaksanaan Hand Hygiene Pada Peserta Program Pendidikan Profesi Dokter. Jurnal Universitas Muhammadiyah Semarang. Diunduh dari http://journals.ums.ac.id.
World Health Organization. (2005). Cuci Tangan Baik dan Benar. [Online]. Di unduh dari http://websehat.net.

Zulpahiyana. (2013). Efektivitas Simulasi Hand Hygiene pada Handover Keperawatan dalam Meningkatkan Kepatuhan Hand Hygiene Perawat. (Tesis, Universitas Muhammadiyah Yogyakarta). Diunduh dari : http://www.umy.ac.id. 